\title{
Pemberian kombinasi probiotik dan zinc terhadap perubahan kadar hemoglobin, albumin, dan indeks massa tubuh pada pasien tuberkulosis paru
}

The effect of combined probiotics and zinc supplementation on the changes of hemoglobin, albumin level, and body mass index of pulmonary tuberculosis patients

\author{
Meika Rahmawati Arifah ${ }^{1}$, Darmono $^{2}$, Muchlis Achsan Udji Sofro ${ }^{3}$ \\ ${ }^{1}$ Program Studi Magister Ilmu Gizi, Fakultas Kedokteran Universitas Diponegoro \\ Program Studi Ilmu Gizi, Fakultas Kedokteran Universitas Diponegoro \\ ${ }^{3}$ Bagian Penyakit Dalam, Fakultas Kedokteran Universitas Diponegoro / Rumah Sakit Dr. Kariadi
}

\begin{abstract}
Background: TB patients are generally the most productive age group and suffer from chronic energy deficiency. Therefore, patients with TB requires a combination of chemotherapy and supplementary feeding as probiotics and zinc to boost the immune response and nutritional status. Objective: To analyze the effect of a combined of probiotics and zinc on the changes of hemoglobin, albumin level and BMI. Method: This study is a quasi-experimental, randomized design with pre-post test control group involving 52 respondents. They were divided into two groups. The treatment group was given a combination of 1 capsule of probiotics ( 2 billion probiotics) and zinc $20 \mathrm{mg}$ per day for 28 days. Analysis is paired t-test, independent t-test, Mann Whitney, Pearson, Spearman, Covariance. Results: There was an increase in hemoglobin $(p=0.01)$, albumin $(p=0.01)$ and $B M I(p=0.01)$. There is no difference between the two groups in the levels of hemoglobin parameter $(p=0.21)$ and $B M I(p=0.12)$, whereas there is a difference parameter albumin levels ( $p=0.01$ ). The effectiveness of interventions is $4 \%$ for hemoglobin levels, $16 \%$ to albumin, and $1 \%$ for IMT. Conclusion: Probiotics and zinc for 28 days in patients with pulmonary tuberculosis may increase levels of hemoglobin, albumin and BMI, but there is no significant difference in the changes of BMI. The most powerful influence of intervention effectiveness is on albumin.
\end{abstract}

KEY WORDS: albumin; BMI; hemoglobin; probiotics; pulmonary tuberculosis; zinc

\begin{abstract}
ABSTRAK
Latar belakang: Penderita TB paru pada umumnya menderita kekurangan energi kronis, defisiensi zinc, dan retinol plasma sehingga memerlukan kombinasi pengobatan kemoterapi dan pemberian makanan tambahan seperti probiotik dan zinc yang dapat meningkatkan respon imun dan status gizi. Tujuan: Menganalisis pengaruh pemberian kombinasi probiotik dan zinc terhadap perubahan kadar hemoglobin, kadar albumin, dan IMT. Metode: Penelitian eksperimen semu dengan rancangan randomized prepost test control group design yang melibatkan 52 responden yang dibagi menjadi 2 kelompok secara acak. Kelompok perlakuan diberikan 1 kapsul probiotik ( 2 milyar) dan zinc $20 \mathrm{mg}$ per hari dan kelompok kontrol diberikan placebo probiotik dan zinc selama 28 hari. Analisis yang dilakukan adalah uji paired t-test, independent t-test, Mann Whitney, Pearson, Spearman, dan Covariance. Hasil: Terdapat peningkatan kadar hemoglobin $(\mathrm{Hb})(\mathrm{p}=0,01)$; albumin $(\mathrm{p}=0,01)$; dan IMT $(\mathrm{p}=0,01)$. Tidak terdapat perbedaan antara 2 kelompok pada parameter kadar $\mathrm{Hb}(\mathrm{p}=0,21)$ dan IMT $(\mathrm{p}=0,12)$ sedangkan kadar albumin terdapat perbedaan $(\mathrm{p}=0,01)$. Efektivitas intervensi $4 \%$ untuk kadar $\mathrm{Hb}, 16 \%$ untuk kadar albumin, dan 1\% untuk IMT. Simpulan: Pemberian probiotik dan zinc selama 28 hari pada penderita TB paru dapat meningkatkan kadar Hb, kadar albumin, dan IMT. Namun, perubahan IMT tidak ada perbedaan signifikan. Efektifitas intervensi paling kuat berpengaruh terhadap kadar albumin.
\end{abstract}

KATA KUNCI: albumin; IMT; hemoglobin; probiotik; TB paru; zinc

Korespondensi: Meika Rahmawati Arifah, Program Studi Magister Ilmu Gizi Fakultas Kedokteran Universitas Diponegoro, Jl. Kanfer Utara 2 No. 59, Pedalangan, Banyumanik, Semarang, Indonesia, e-mail: meikaraha@gmail.com 


\section{PENDAHULUAN}

Tuberkulosis paru (TB paru) menjadi masalah kesehatan di seluruh negara khususnya negara miskin dan berkembang serta menyebabkan hampir 2 juta kematian per tahun di seluruh dunia (1). Penderita TB paru di Indonesia umumnya merupakan kelompok usia produktif dan menderita kekurangan energi kronis $(2,3)$. Pasien TB paru mengalami perubahan metabolisme yang disebabkan sitokin-sitokin pro inflamasi (IFNdan TNF- $\alpha$ ) yang disekresi sel-sel imun sebagai respon imunitas terhadap infeksi bakteri TB. Hal ini diduga menjadi penyebab yang sering menimbulkan terjadinya kekurangan energi kronis, anoreksia, dan demam (4,5). Kondisi ini mengakibatkan penurunan berat badan yang drastis (6). Hal ini tentu saja membuat pasien TB memiliki status gizi yang lebih buruk daripada orang sehat dan umumnya memiliki kadar albumin darah kurang dari normal (7). Kadar albumin yang rendah berhubungan dengan kejadian anemia pada pasien tuberkulosis (8). Anemia juga bisa disebabkan karena infeksi kronik dan peningkatan IL-6 yang merupakan salah satu mediator inflamasi yang turut menstimulasi penyimpanan serta retensi Fe di dalam makrofag $(9,10)$.

Obat anti TB terdiri dari beberapa obat yang bersifat bakterisid dan merupakan antibiotika yang membunuh bakteri dan akan mengganggu keseimbangan mkroflora usus, karena menyebabkan perubahan komposisi microflora usus (11-13). Efek samping lainnya dari obat anti TB ini adalah mual muntah sehingga pasien TB kehilangan selera makan dan pada akhirnya banyak yang mengalami penurunan berat badan (13). Akan tetapi, pengobatan kemoterapi menggunakan obat anti tuberkulosis (OAT), mampu menurunkan peradangan dan kenaikan berat badan (14).

Penyembuhan penyakit TB paru, memerlukan perbaikan pada indikator-indikator penting seperti menurunnya inflamasi, meningkatnya respon imun dan sintesis sel-sel imunitas sebagai akibat membaiknya ekspresi gen (transkripsi dan translasi). Perubahan positif pada indikator-indikator ini sangat ditentukan oleh keseimbangan protein tubuh (15). Perbaikan ini bisa dilakukan dengan beberapa cara diantaranya dengan pengobatan TB, pemberian makanan tambahan seperti sinbiotik, zinc, vitamin A, dan protein. Kombinasi pengobatan kemoterapi dan pemberian makanan tambahan dapat meningkatkan respon imun dan lebih cepat menghasilkan kesembuhan (3).

Fungsi probiotik dan zinc dalam saluran pencernaan hampir sama yaitu meningkatkan sistem kekebalan tubuh. Pemberian kombinasi sinbiotik, vitamin A, dan zinc pada pasien TB selama 56 hari dapat meningkatkan berat badan, indeks massa tubuh (IMT), lemak tubuh, dan hemoglobin (Hb) (15). Pada penelitian ini variabel albumin dan asupan energi dan protein pasien TB belum dianalisis. Studi lain menyatakan bahwa pemberian zinc tunggal mampu meningkatkan rata-rata berat badan pasien TB akan tetapi membutuhkan waktu yang lebih lama yaitu 7 bulan (16). Pada kasus TB, probiotik spesies Lactobacillus mampu menekan pertumbuhan Mycobacterium B5 karena tahan terhadap keasaman sistem pencernaan dan antibiotik yang digunakan untuk pengobatan TB (17).

Tujuan dari penelitian ini adalah untuk membuktikan pengaruh pemberian kombinasi probiotik dan zinc terhadap perubahan kadar $\mathrm{Hb}$, kadar albumin, dan IMT pada pasien TB paru. Manfaat dari penelitian ini adalah untuk memberikan informasi kepada masyarakat tentang manfaat kombinasi probiotik dan zinc yang dapat meningkatkan status gizi pasien TB paru.

\section{BAHAN DAN METODE}

Penelitian dilakukan di Balai Kesehatan Paru Masyarakat, Semarang pada bulan November 2015Januari 2016. Populasi dalam penelitian ini adalah semua pasien TB paru yang menjalani perawatan atau terapi OAT di Balai Kesehatan Paru Masyarakat Semarang. Sampel merupakan sebagian dari populasi target yang diambil secara consecutive sampling dengan kriteria inklusi yaitu bersedia menjadi subjek penelitian dengan menandatangani informed consent; laki-laki atau perempuan berusia usia 18 - 60 tahun; jika perempuan, tidak dalam kondisi hamil; menjalani awal pengobatan TB paru standar dalam masa intensif (obat yang diberikan sama yaitu isoniasid, rifampisin, pirazinamid, etambutol). Kriteria eksklusi yaitu pasien TB paru yang terkena human immunodeficiency virus (HIV), TB, sepsis, terpasang naso gastric tube (NGT), dan pasien yang 
mendapatkan tambahan suplemen zat gizi mikro (vitamin C, zinc, dan besi).

Penelitian ini merupakan penelitian eksperimen semu (quasi experiment) dengan rancangan randomized pre-post test control group design. Subjek dipilih secara consecutive sampling dengan jumlah responden 54 orang, kemudian dibagi menjadi 2 kelompok yaitu kelompok kontrol (27 orang) dan kelompok perlakuan (27 orang). Kelompok perlakuan diberikan kombinasi probiotik (merk Lacidofil) dan zinc sedangkan kelompok kontrol diberikan plasebo. Intervensi diberikan selama 28 hari sejalan dengan penelitian sebelumnya (15). Responden tidak mengetahui apakah sebagai kelompok kontrol atau sebagai kelompok perlakuan (single blind). Dosis probiotik 1 kapsul (2 milyar probiotik dengan spesies Lactobacillus helveticus Rossell-52 dan Lactobacillus rhamnosus Rosell-11) dan zinc $20 \mathrm{mg}$ per hari. Sementara plasebo probiotik dan zinc berisi amylum sativa dan berbentuk kapsul. Warna, ukuran, dan bentuk disesuaikan dengan kapsul lacidofil dan zinc. Sebelum dan sesudah intervensi selama 4 minggu, pasien TB paru pada kedua kelompok tersebut akan dilakukan pengukuran terhadapt tiga variabel terikat yaitu kadar $\mathrm{Hb}$, albumin, dan IMT.

Pengukuran kadar $\mathrm{Hb}$ dengan metode hematologi analyser, kadar albumin dengan metode brom cresol green (BCG), dan IMT dengan menghitung berat badan $(\mathrm{kg})$ dibagi dengan kuadrat tinggi badan $(\mathrm{m})$. Berat badan diukur dengan menggunakan alat timbangan injak digital dengan tingkat ketelitian $0,1 \mathrm{~kg}$. Tinggi badan diukur menggunakan microtoise dengan tingkat ketelitian 0,1 $\mathrm{cm}$. Asupan energi, protein, vitamin $\mathrm{C}$, dan besi yang dikonsumsi subjek diperoleh dengan menggunakan metode food recall 3×24 jam kemudian hasilnya dihitung menggunakan program nutrisurvey dan dibandingkan dengan angka kecukupan gizi (AKG) tahun 2013. Uji statistik yang digunakan adalah independent t-test, paired t-test, uji Pearson, uji Spearman, uji covariance, uji Mann-Whitney, dan uji Wilcoxon. Surat ethical clearance diterbitkan oleh Komisi Etik Penelitian Kesehatan Fakultas Kedokteran Universitas Diponegoro Semarang dengan nomor 630/EC/FK-RSDK/2015.

\section{HASIL}

\section{Karakteristik subjek}

Pada kelompok perlakuan, sebagian besar subjek berjenis kelamin laki-laki $(77,8 \%)$ dengan rerata usia 43,2 tahun, bekerja sebagai wiraswasta $(55,6 \%)$, dan berpendidikan terakhir SMP (44,4\%). Rerata kadar awal Hb sebesar 13,1 g/dl, kadar awal albumin 3,8 g/dl, dan IMT awal sebesar 19,6 kg/m². Sementara pada kelompok kontrol, sebagian besar subjek berjenis kelamin laki-laki (55,6\%), rerata usia 41,5 tahun, bekerja sebagai pegawai swasta $(55,6 \%)$, dan pendidikan terakhir SMP $(55,6 \%)$ (Tabel 1).

Tabel 1. Deskripsi karakteristik subjek

\begin{tabular}{|c|c|c|c|c|}
\hline \multirow{3}{*}{ Variabel } & \multicolumn{4}{|c|}{ Kelompok } \\
\hline & \multicolumn{2}{|c|}{ Perlakuan $(n=27)$} & \multicolumn{2}{|c|}{ Kontrol $(n=27)$} \\
\hline & n & $\%$ & $\mathbf{n}$ & $\%$ \\
\hline \multicolumn{5}{|l|}{ Jenis kelamin } \\
\hline Laki-laki & 21 & 78 & 15 & 56 \\
\hline Perempuan & 6 & 22 & 12 & 44 \\
\hline \multicolumn{5}{|l|}{ Pendidikan terakhir } \\
\hline Tidak sekolah & 9 & 33 & 3 & 11 \\
\hline $\mathrm{SD}$ & 3 & 11 & 1 & 4 \\
\hline SMP & 12 & 45 & 15 & 56 \\
\hline SMA & 0 & 0 & 2 & 7 \\
\hline Perguruan tinggi & 3 & 11 & 6 & 22 \\
\hline \multicolumn{5}{|l|}{ Pekerjaan } \\
\hline Tidak bekerja & 0 & 0 & 2 & 7 \\
\hline Buruh & 3 & 11 & 0 & 0 \\
\hline Ibu rumah tangga & 2 & 7 & 2 & 7 \\
\hline Pegawai swasta & 5 & 19 & 15 & 56 \\
\hline Wiraswasta & 15 & 56 & 7 & 26 \\
\hline PNS & 2 & 7 & 1 & 4 \\
\hline
\end{tabular}

Tabel 2. Rerata usia, kadar Hb, albumin, dan IMT subjek di awal penelitian

\begin{tabular}{|c|c|c|c|c|c|}
\hline \multirow{2}{*}{ Karakteristik } & \multicolumn{2}{|c|}{ Perlakuan } & \multicolumn{2}{|c|}{ Kontrol } & \multirow[b]{2}{*}{ p } \\
\hline & Median & Rerata \pm SD & Median & Rerata \pm SD & \\
\hline Usia (tahun) & 44 & $43,2 \pm 14,2$ & 43 & $41,5 \pm 11,7$ & 0,64 \\
\hline Kadar $\mathrm{Hb}^{1}(\mathrm{~g} / \mathrm{dl})$ & 13,2 & $13,1 \pm 2,2$ & 13,1 & $13,2 \pm 1,6$ & 0,89 \\
\hline Kadar albumin (g/dl) & 3,9 & $3,8 \pm 0,6$ & 4,28 & $4,2 \pm 0,3$ & $0,03 *$ \\
\hline $\mathrm{IMT}^{2}$ & 19,1 & $19,6 \pm 3,1$ & 20,6 & $20,9 \pm 4,3$ & 0,18 \\
\hline
\end{tabular}

${ }^{1} \mathrm{Hb}=$ hemoglobin; ${ }^{2} \mathrm{IMT}=$ indeks massa tubuh; $*=$ signifikan $(\mathrm{p}<0,05)$ 
Tabel 3. Perubahan parameter kadar Hb, albumin, dan IMT

\begin{tabular}{|c|c|c|c|}
\hline Variabel & $\begin{array}{c}\text { Perlakuan } \\
\text { Rerata } \\
\pm \text { SD } \\
\end{array}$ & $\begin{array}{c}\text { Kontrol } \\
\text { Rerata } \\
\pm \text { SD } \\
\end{array}$ & $\mathbf{p}$ \\
\hline \multicolumn{4}{|l|}{ Kadar $\mathrm{Hb}$} \\
\hline Sebelum perlakuan & $13,1 \pm 2,2$ & $13,2 \pm 1,6$ & $0,89^{\mathrm{c}}$ \\
\hline Setelah 4 minggu & $13,6 \pm 1,9$ & $13,4 \pm 1,3$ & $0,52^{\mathrm{c}}$ \\
\hline$\Delta$ kadar hemoglobin $(\mathrm{g} / \mathrm{dl})$ & $0,5 \pm 1,1$ & $0,1 \pm 0,7$ & $0,21^{\mathrm{c}}$ \\
\hline $\mathrm{p}$ & $0,01^{\mathrm{a}}$ & $0,22^{\mathrm{a}}$ & \\
\hline \multicolumn{4}{|l|}{ Kadar albumin } \\
\hline Sebelum perlakuan & $3,8 \pm 0,6$ & $4,2 \pm 0,3$ & $0,01^{\mathrm{c}}$ \\
\hline Setelah 4 minggu & $4,1 \pm 0,4$ & $4,0 \pm 0,4$ & $0,82^{\mathrm{b}}$ \\
\hline$\Delta$ kadar albumin $(\mathrm{g} / \mathrm{dl})$ & $0,2 \pm 0,4$ & $-0,2 \pm 0,2$ & $0,01^{\mathrm{b}}$ \\
\hline $\mathrm{p}$ & $0,01^{\mathrm{a}}$ & $0,01^{\mathrm{d}}$ & \\
\hline \multicolumn{4}{|l|}{ IMT } \\
\hline Sebelum perlakuan & $19,6 \pm 3,1$ & $20,9 \pm 4,3$ & $0,18^{\mathrm{c}}$ \\
\hline Setelah 4 minggu & $20,2 \pm 3,2$ & $21,4 \pm 4,3$ & $0,27^{\mathrm{c}}$ \\
\hline$\Delta \mathrm{IMT}$ & $0,6 \pm 1,0$ & $0,4 \pm 0,5$ & $0,12^{\mathrm{b}}$ \\
\hline $\mathrm{p}$ & $0,02^{\mathrm{a}}$ & $0,01^{\mathrm{a}}$ & \\
\hline
\end{tabular}

$\mathrm{a}=$ paired $t$ test $; \mathrm{b}=$ Mann-Whitney; $\mathrm{c}=$ independent $t$-test; $\mathrm{d}=$ Wilcoxon

Tabel 4. Hubungan asupan zat gizi dengan perubahan kadar Hb, albumin, dan IMT

\begin{tabular}{lccc}
\hline \multirow{2}{*}{ Variabel } & \multicolumn{3}{c}{$\mathbf{p}$} \\
\cline { 2 - 4 } & $\Delta \mathbf{H b}$ & $\Delta$ Albumin & $\Delta$ IMT \\
\hline Asupan energi & $0,50^{\mathrm{a}}$ & $0,08^{\mathrm{a}}$ & $0,47^{\mathrm{a}}$ \\
Asupan protein & $0,75^{\mathrm{a}}$ & $0,13^{\mathrm{a}}$ & $0,28^{\mathrm{a}}$ \\
Asupan vitamin C & $0,08^{\mathrm{b}}$ & $0,99^{\mathrm{b}}$ & $0,26^{\mathrm{b}}$ \\
Asupan besi & $0,87^{\mathrm{b}}$ & $0,06^{\mathrm{b}}$ & $0,76^{\mathrm{b}}$ \\
\hline
\end{tabular}

$\mathrm{a}=$ uji Pearson $; \mathrm{b}=$ uji Spearman

Rerata kadar awal Hb 13,2 g/dl, kadar awal albumin $4,2 \mathrm{~g} / \mathrm{dl}$, dan IMT awal $20,9 \mathrm{~kg} / \mathrm{m}^{2}$. Hasil independent t-test menunjukkan tidak ada perbedaan antara rerata usia, kadar Hb awal, IMT awal ( $p>0,05)$ sedangkan kadar albumin awal menunjukkan ada perbedaan $(\mathrm{p}<0,05)$ (Tabel 2).

Hasil uji statistik dengan paired t-test menunjukkan peningkatan kadar $\mathrm{Hb}(\mathrm{p}=0,01)$, albumin $(\mathrm{p}=0,01)$, dan IMT $(p=0,02)$ pada kelompok perlakuan. Hasil uji statistik independent t-test menunjukkan tidak ada perbedaan antara kedua kelompok pada parameter perubahan kadar $\mathrm{Hb}(\mathrm{p}=0,21)$. Hasil uji statistik MannWhitney menunjukkan tidak ada perbedaan antara kedua kelompok pada parameter perubahan IMT $(p=0,12)$ sedangkan hasil uji statistik Mann-Whitney menunjukkan perbedaan pada parameter perubahan kadar albumin $(p=0,01)($ Tabel 3).
Tabel 5. Perbedaan intervensi terhadap perubahan kadar Hb, albumin, dan IMT

\begin{tabular}{|c|c|c|c|c|c|}
\hline \multirow{2}{*}{ Variabel } & \multicolumn{2}{|c|}{ Kelompok } & \multirow{2}{*}{$\mathbf{F}$} & \multirow{2}{*}{$p^{2}$} & \multirow{2}{*}{$\begin{array}{c}\text { Partial eta } \\
\text { squared }\end{array}$} \\
\hline & Perlakuan & Kon & & & \\
\hline$\overline{\mathrm{Kad}}$ & $13,6 \pm 1,9$ & $13,4 \pm$ & 2,46 & 0,12 & 0,04 \\
\hline Kade & $4,1=$ & 4,0 & 10,27 & 0,01 & 0 , \\
\hline MT & $20,2 \pm 3,2$ & $21,4 \pm 4,3$ & 0,67 & 0,41 & 0,01 \\
\hline
\end{tabular}

Tidak ada hubungan yang signifikan antara asupan energi dan protein (uji Pearson) serta vitamin C dan besi (uji Spearman) terhadap perubahan kadar $\mathrm{Hb}$, kadar albumin, dan IMT ( $>00,05)$ (Tabel 4). Uji covariance menunjukkan efektivitas intervensi sebesar 4\% untuk kadar $\mathrm{Hb}, 16 \%$ untuk kadar albumin, dan 1\% untuk IMT (Tabel 5).

\section{BAHASAN}

Sebagian besar subjek penelitian ini berjenis kelamin laki-laki. Hal ini sesuai dengan penelitian sebelumnya yang menyatakan bahwa laki-laki cenderung lebih banyak menderita TB paru dibandingkan perempuan karena mungkin disebabkan oleh status sosial dan pekerjaan laki-laki yang lebih berpotensi untuk terpapar bakteri Mycobacteria tuberculosis. Lingkungan pekerjaan dan seringnya berinteraksi dengan orang lain dapat mempengaruhi tingkat penularan karena kontak dengan orang yang menderita TB paru $(18,19)$. Kebiasaan merokok tembakau dan minum alkohol pada laki-laki dapat menurunkan sistem pertahanan tubuh sehingga lebih mudah terpapar dengan bakteri Mycobacteria tuberculosis (20). Berdasarkan data Riset Kesehatan Dasar (Riskesdas) tahun 2013 dan hasil penelitian di Bandung menyatakan bahwa prevalensi TB paru cenderung meningkat pada pendidikan rendah $(21,22)$. Penelitian sebelumnya juga menyatakan bahwa penyakit TB paru mudah menyerang kelompok masyarakat dengan pengetahuan tentang hygiene sanitasi yang rendah, kemampuan menjalani pengobatan dengan tidak benar dan keadaan malnutrisi atau kekurangan kalori, protein, vitamin, zat besi dan lain-lain yang akan mempengaruhi daya tahan tubuh seseorang sehingga rentan terhadap penyakit termasuk TB paru (20,23). Pengetahuan berkaitan langsung dengan tingkat pendidikan seseorang. Semakin tinggi pendidikan seseorang, semakin bertambah tingkat pengetahuannya tentang hygiene sanitasi, kemampuan menjalani 
pengobatan, dan makanan bergizi yang bermanfaat untuk sistem imunitas (24). Penyakit TB paru paling sering ditemukan pada usia produktif yaitu usia 15-50 tahun. Tingkat penularan penyakit ini lebih tinggi pada usia produktif karena lebih sering berinteraksi dengan lingkungan sekitar yang terpapar bakteri Mycobacteri tuberculosis dan kontak dengan orang yang menderita TB paru $(18,21,25)$.

Rerata kadar $\mathrm{Hb}$ awal subjek pada kelompok perlakuan sebesar 13,1 $\mathrm{g} / \mathrm{dl}$ dan pada kelompok kontrol sebesar 13,2 g/dl. Hal ini berbeda dengan penelitian sebelumnya yang menyatakan bahwa sebagian besar penderita TB paru mengalami anemia $(9,26)$. Hal ini kemungkinan karena prevalensi tertinggi anemia terjadi pada ibu hamil, lansia, bayi, anak 1-2 tahun, anak sekolah, wanita tidak hamil, dan anak prasekolah (27) sedangkan sebagian besar subjek penelitian ini berjenis kelamin laki-laki dengan usia produktif. Selain itu, bisa juga dimungkinkan karena kadar interleukin-6 (IL-6) subjek penelitian ini tidak terlalu tinggi. Interleukin-6 merupakan salah satu mediator inflamasi yang turut menstimulasi penyimpanan dan retensi Fe di dalam makrofag dalam patogenesis terjadinya anemia penyakit kronik yang merupakan jenis anemia terbanyak yang diderita oleh pasien tuberkulosis $(9,10)$.

Rerata kadar albumin awal subjek pada kelompok perlakuan sebesar 3,8 g/dl dan pada kelompok kontrol sebesar 4,2 g/dl. Hal ini menunjukkan bahwa kadar albumin kedua kelompok tergolong normal sesuai dengan hasil penelitian di Manado yang menyatakan bahwa $67,3 \%$ respondennya memiliki kadar albumin normal (28). Salah satu faktor yang mempengaruhi status gizi pada pasien TB adalah lama menderita TB paru. Status gizi penderita kasus TB baru pada umumnya masih normal, berbeda dengan kasus TB lama yang mengalami status gizi kurang (28-30).

Rerata kadar IMT awal subjek pada kelompok perlakuan sebesar $19,6 \mathrm{~kg} / \mathrm{m}^{2}$ dan pada kelompok kontrol sebesar 20,9 kg/m². Hal ini berarti IMT kedua kelompok normal sejalan dengan penelitian sebelumnya yang menyatakan bahwa $75 \%$ respondennya memiliki IMT normal (28). Pasien TB paru aktif akan mengalami penurunan berat badan dan nafsu makan, tetapi memiliki nilai IMT normal. Hal ini bisa terjadi kemungkinan karena prevalensi status gizi normal (perawakan normal dan pendek) pada orang dewasa cukup tinggi ( $62,7 \%)$ dan cenderung mengalami pergeseran ke arah obesitas (21).

Hasil analisis menunjukkan peningkatan kadar $\mathrm{Hb}(\mathrm{p}=0,01)$, albumin $(\mathrm{p}=0,01)$, dan IMT $(\mathrm{p}=0,02)$ pada kelompok perlakuan. Hasil analisis juga menunjukkan perbedaan signifikan pada parameter perubahan kadar albumin $(\mathrm{p}=0,01)$ antara kedua kelompok. Probiotik mampu meningkatkan penyerapan zat gizi seperti vitamin, antioksidan, besi, kalsium, magnesium, dan seng serta menurunkan derajat inflamasi. Menurunnya tingkat inflamasi saluran pencernaan dan membaiknya nafsu makan responden menjadi faktor yang menentukan kenaikan kadar Hb, albumin, dan IMT. Penelitian sebelumnya membuktikan pemberian sinbiotik, suplemen susu, dan zat gizi mikro mampu meningkatkan $\mathrm{Hb}$, berat badan, dan IMT (15,31). Pada kasus TB, probiotik spesies Lactobacillus mampu menekan pertumbuhan Mycobacterium B5 karena tahan terhadap keasaman sistem pencernaan dan antibiotik yang digunakan untuk pengobatan TB (17).

Adanya inflamasi akan menekan sintesis albumin. Hasil penelitian di Jepang dan Cina menyatakan bahwa pemberian probiotik dapat meningkatkan kadar $\mathrm{Hb}$, albumin, dan dapat menurunkan TNF- $\alpha$ atau respon inflamasi. Terdapat peningkatan aktivitas fagosit darah atau penanda kekebalan alami $(32,33)$. Pemberian probiotik disertai dengan asupan nutrisi yang memadai pada babi telah terbukti meningkatkan biosintesis albumin dalam waktu 14 hari (34). Probiotik mampu melakukan induksi gen yang terlibat dalam regulasi transkripsi dan sintesis protein (35). Pada kelompok kontrol juga ditemukan adanya kenaikan IMT, hal ini bisa disebabkan oleh pengobatan kemoterapi menggunakan obat anti tuberkulosis (OAT) yang mampu menurunkan peradangan dan kenaikan berat badan (14).

Efek probiotik dan zinc dalam saluran pencernaan hampir sama yaitu efek imunomodulasi. Pada zinc terdapat efek yang lain yaitu memproteksi kuman patogen dan mempertahankan integritas barier (36,37). Di samping itu, zinc mempengaruhi regenerasi dan fungsi vili usus sehingga akan mempengaruhi pembentukan enzim disakaridase yaitu laktase, sukrose, dan maltase yang mempengaruhi transportasi natrium $(\mathrm{Na})$ dan glukosa 
(38). Pemberian zinc dapat meningkatkan nafsu makan dan ketajaman rasa pengecap pada lidah. Hasil penelitian pada balita dengan suplementasi zinc menunjukkan bahwa sebagian besar balita mengalami kenaikan status gizi (39). Pemberian suplemen vitamin A dan zinc pada pasien TB dapat menurunkan kadar IL-6 (40). Membaiknya nafsu makan dan menurunnya inflamasi pada pasien TB paru menjadi faktor menentukan kenaikan kadar $\mathrm{Hb}$, kadar albumin, dan IMT.

\section{SIMPULAN DAN SARAN}

Tidak ada pengaruh pemberian kombinasi probiotik dan zinc terhadap kadar Hb dan IMT. Terdapat peningkatan kadar albumin secara signifikan pada kelompok perlakuan $(p=0,01)$ dan sebaliknya pada kelompok kontrol terjadi penurunan albumin yang signifikan $(\mathrm{p}=0,01)$. Terdapat perbedaan signifikan pada parameter perubahan kadar albumin antara kelompok perlakuan dan kontrol $(\mathrm{p}=0,01)$. Efektivitas intervensi paling kuat berpengaruh terhadap kadar albumin. Perlu dilakukan penelitian lebih lanjut tentang perhitungan asupan makan responden setiap hari dan kandungan obat lain yang berpengaruh terhadap nafsu makan pada pasien TB paru.

\section{Pernyataan konflik kepentingan}

Penulis menyatakan tidak ada konflik kepentingan dengan pihak-pihak yang terkait dalam penelitian ini.

\section{RUJUKAN}

1. WHO. WHO Report 2009: Global tuberculosis control epidemiology, strategy, financing. Geneva, Switzerland: WHO Press; 2009.

2. Paton NI, Chua YK, Earnest A, Chee CBE. Randomized controlled trial of nutritional supplementation in patients with newly diagnosed tuberculosis and wasting. Am J Clin Nutr 2004;80(2):460-5.

3. Sahiratmadja E, Alisjahbana B, de Boer T, Adnan I, Maya A, Ottenhoff TH, et al. Dynamic changes in pro- and antiinflammatory cytokine profiles and gamma interferon receptor signaling integrity correlate with tuberculosis disease activity and response to curative treatment. Infect Immun 2007;75(2):820-9.

4. Verbon A, Juffermans NP, van Deventer SJ. Serum concentration of cytokines in patients with active tuberculosis and after treatment. Clin Exp Immunol 199; 115:110-3.

5. Juffermans NP, Verbon A, van Deventer SJ, van Deutekom H, Speelman P, van der Poll T. Tumor necrosis factor and interleukin-1 inhibitors as marker of disease activity of tuberculosis. Am J Respir Crit Car Med 1998;157(4 Pt 1):1328-31.

6. Gupta H, Kant S, Jain A, Ahluwalia S, Natu S. Association of nutritional factors with tuberculosis treatment outcome. Proceedings published in International Journal of Computer Applications ${ }^{\circledR}$ (IJCA) $(0975$ - 8887). National Seminar on Application of Artificial Intelligence in Life Sciences (NSAAILS - 2013); 2013.

7. Karyadi E, West CE, Schultink W, Nelwan RHH, Gross R, van der Meer JW. A double-blind, placebo controlled study of vitamin A and zinc supplementation in persons with tuberculosis in Indonesia: effects on clinical response and nutritional status. Am J Clin Nutr 2002;75(4):720-7.

8. Karyadi E, Schultink W, Nelwan RHH, Gross R, Amin Z, West CE, et al. Poor micronutrient status of active pulmonary tuberculosis patients in Indonesia. J Nutr 2000;130(12):2953-8.

9. Lee SW, Kang YA, Yoon YS, Um SW, Lee SM, Yim JJ, et al. The prevalence and evolution of anemia with tuberculosis. J Korean Med Sci 2006;21(6):1028-32.

10. Weiss G, Goodnough LT. Anemia of chronic disease. N Engl J Med 2005;352:1011-23.

11. Sanders ME. Consideration for use of probiotic bacteria to modulate human health. J Nutr 2000;130(2S Suppl):384S$390 \mathrm{~S}$.

12. Sullivan A, Nord CE. Probiotic in human infection. J Antimicrob Chemother 2002;50(5):625-7.

13. WHO. The stop TB strategy. [series online] 2010 [cited 2015 Jun 5]. Available from: URL: http://www.who.int/ tb/strategy/stop_tb_strategy/en/

14. Alisjahbana B. Tuberculosis in indonesia: host response and patients care [Dissertation]. The Netherlands: Universiteit Nijmegen; 2007.

15. Suparman, Hardinsyah, Kusharto CM, Sulaeman A, Alisjahbana B. Efek pemberian suplemen sinbiotik dan zat gizi mikro (vitamin A dan zinc) terhadap status gizi penderita TBC paru orang dewasa yang mengalami kekurangan energi kronik. Gizi Indon 2011:32-42.

8. Range N, Andersen AB, Magnussen P, Mugomela A, Friis $\mathrm{H}$. The effect of micronutrient supplementation on treatment outcome in patients with pulmonary tuberculosis: a randomized controlled trial in Mwanza, Tanzania. Trop Med Int Health 2005;10(9):826-32.

9. Gavrilova NN, Ratnikova IA, Sadanov AK, Bayakisheva K, Tourlibaeva ZJ, Belikova OA. Application of probiotics 
in complex treatment of tuberculosis. Int. Journal of Engineering Research and Applications 2014:4(11):13-8.

10. Sihombing H, Sembiring H, Amir Z, Sinaga B. Pola resistensi primer pada penderita $\mathrm{TB}$ paru kategori I di RSUP H. Adam Malik, Medan. J Respir Indo 2012;32(3):138-45.

11. Pertiwi R, Wuryanto MA, Sutiningsih D. Hubungan antara karakteristik individu, praktik hygiene dan sanitasi lingkungan dengan kejadian tuberculosis di Kecamatan Semarang Utara Tahun 2011. Jurnal Kesehatan Masyarakat 2012;1(2):434-45.

16. Hiswani. Tuberkulosis merupakan penyakit infeksi yang masih menjadi masalah kesehatan masyarakat. [series online] 2009 [cited 2016 Jan 23]. Available from: URL: http://librarv.usu.ac.id/download/fkmhiswani6.pdf

17. Kementerian Kesehatan. Riset kesehatan dasar (Riskesdas) tahun 2013. Jakarta: Kementerian Kesehatan RI; 2013

18. Herryanto D, Musadad DA, Komalig FM. Riwayat pengobatan penderita TB paru meninggal di Kabupaten Bandung. Jurnal Ekologi Kesehatan 2004;3(1):1-6.

19. Departemen Kesehatan Republik Indonesia. Pedoman nasional penanggulangan tuberkulosis. cetakan ke 6 . Jakarta: Departemen Kesehatan Republik Indonesia; 2001.

20. Suswati E. Hubungan tingkat pendidikan dengan kepatuhan minum obat pada penderita tuberkulosis paru. Pengembangan Pendidikan 2006;3(1):67-73.

21. Manalu HSP. Faktor-faktor yang mempengaruhi kejadian TB paru dan upaya penanggulangannya. Jurnal Ekologi Kesehatan 2010;9(4):1340-6.

22. Martina AD. Hubungan usia, jenis kelamin dan status nutrisi dengan kejadian anemia pada pasien tuberkulosis. Media Medika Muda 2012;1(1).

23. Ramakrishnan U. Nutritional anemias. New York Washingon, DC: CRC Press, Boca London; 2001.

24. Puspitasari P, Wongkar MCP, Surachmanto E. Profil pasien tuberkulosis paru RSUP Prof.Dr. R.D. Kandou Manado [skripsi]. Manado: Universitas Sam Ratulangi; 2013.

25. WHO. Global tuberculosis programme: global tuberculosis control. Geneva: WHO report; 2013.

26. Dye C, Scheele S, Dolin P, Pathana V, Raviglione MC. Consensus statement. Global burden of tuberculosis: estimated incidence, prevalence, and mortality by country.
WHO Global Surveillance and Monitoring Project. JAMA 1999;282(7):677-86.

27. Rahmadani RP. Aplikasi yoghurt dan koumiss susu kambing probiotik dengan penambahan ekstrak kelopak bunga Rosella (Hibiscus sabdariffa) sebagai pangan terapis bagi penderita tuberkulosis paru. Bogor: Program Kreativitas Mahasiswa-Penelitian Institut Pertanian Bogor; 2013.

28. Fukushima Y, Miyaguchi S, Yamano T, Kaburagi T, Iino H, Sato K. Improvement of nutritional status and incidence of infection in hospitalised, enterally fed elderly by feeding of fermented milk containing probiotic Lactobacillus johnsonii La1 (NCC533). Br J Nutr 2007;98(5):969-77.

29. Lu X, Han CM, Yu JX, Fu SZ. Preliminary comparative study on the effects of early enteral supplementation of synbiotics on severely burned patients. Zhonghua Shao Shang Za Zhi 2004;20(4):198-201.

30. Harding SV, Fraser KG, Wykes LJ. Probiotics stimulate liver and plasma protein synthesis in piglets with dextran sulfate-induced colitis and macronutrient restriction. J Nutr 2008;138(11):2129-35.

31. Jeschke MG, Klein D, Herndon DN. Insulin treatment improves the systemic inflammatory reaction to severe trauma. Ann Surg 2004;239(4):553-60.

32. Fischer Walker C, Black RE. Zinc and the risk for infectious disease. Annu Rev Nutr 2004;24:255-75.

33. Berdanier CD, Zempleni J. Advanced nutrition: macronutriens, micronutrients and metabolism. Boca Raton: CRC Press; 2009.

34. Artana WD, Suraatmaja S, Aryasa KN, Suandi IKG. Peran suplementasi mineral mikro seng terhadap kesembuhan diare. Sari Pediatri 2005;7(1):15-8.

35. Suharto, Saptaningrum E, Wijayanti K, Sutarmi, Warijan, Hendromastuti A, et al. The influence of zinc supplementation on nutritional status among children under five years of age at Blora District. Jurnal Ilmu Keperawatan Indonesia 2011;1(1):1-9.

36. Karyadi E, Pakasi TA, Nelwan RHH, Amin Z, Dolmans WMV, et al. The effects of vitamin A and zinc supplementation on cytokines in patients treated for tuberculosis - results from two randomised placebocontrolled trials. Nijmegen, Netherlands: Radboud University; 1972. 